\title{
Cultivating Students' Innovative Ability Based on Engineering Project Practice Course
}

\author{
Zhanxiu Cai, Chunguang Ling, Bo Lian, Xiaodong Wang, Chao Ji, Haoyu Wang, Zhaoyun Qiu* \\ Weifang Medical University \\ Weifang Medical University: School of Bioscience and Technology \\ School of Bioscience and Technology, Electronic and Computer Technology \\ China \\ cai.zhan.xiu@163.com
}

\begin{abstract}
With the aim to train innovative talents for nation, we propose "Practice Course of Engineering Project" in the biomedical engineering to cultivate students' innovative ability. In order to ensure the purpose of innovation ability training, a series of specific measures are put forward such as strict project selection, reasonable project arrangement, optimization of curriculum, improvement of teaching idea, strengthening supervision and evaluation, etc. Project practice is conducive to cultivating students' functional ability and practical ability. Bring engineering project into Biomedical engineering curriculum system.
\end{abstract}

Keywords-Creativity; Engineering practice; Curriculum integration

\section{INTRODUCTION}

"Outline of the National Medium and Long Term Science and Technology Development Plan (2006-2020)" clearly states that the overall goal of China's scientific and technological development by 2020 is "to enter the ranks of innovative countries". To meet this aim, the Ministry of Education in the "21st Century Education Revitalization Action Plan" put forward "to train and create a number of high level innovative talents aiming at the national innovation system goals." In the literature based on the cultivation of innovation ability, many articles mentioned that project practice is one of the important models of innovation ability cultivation [1].

\section{CURRENT Situation AND ANALYSIS OF ENGINEERING PROJECT}

\section{A. Status of Project Implementation}

China, the largest developing country, has a gap in Engineering practice education comparing with the developed countries. Expert pointed out that the Engineering practice ability of students is seriously inadequate to solve the engineering problems. Other experts also pointed out that Implementation of the project practice of Undergraduate Engineering Education in China is severely weakened.

\section{B. Situation Analysis}

Analysis of the status, academician Shi Mingxian thinks it is due to paying too much attention to the theory, ignoring the practice, lacking of education funding and other factors. In addition, the implementation of our university engineering training mainly rely on enterprise internship and National Undergraduate Innovation Program to achieve. Business internship time is too short because there are too many students, and most students only participated in a part of the entire project in an internship, thus they lack a systematic understanding of the entire project. Researcher Lu Xiaoyan pointed out that there are also time scatter, the contents of practical content are not concerned with the theory problems. Also, because the purpose of profit for the enterprise, advanced technology is protected, therefore, through the practice of students to cultivate innovate ability is difficult to achieve [2]. As for National Undergraduate Innovation Program and all kinds of competition, although it is conducive to stimulate students' enthusiasm for innovation, but due to relatively fewer spaces and is very difficult, only few students can participate. In addition, because project require to be completed in a short time frame, students learn with strong purposiveness, only to learn the knowledge used in the project, it is difficult to ensure the integrity of the knowledge structure.

\section{OVERALL THINKING AND PRINCIPLE OF PROGRAM DESIGN}

In order to effectively solve the problem of the limitation of practical time, dispersed arrangements and a fairly weak link between projects, incorporating the "Project Practice Course" into curriculum system of biomedical engineering through revising the training plan is proposed. The entire course runs through the second to the fourth year, with a total of 80 standard hours

In order to maximize the advantage of the "project practice course" in the innovation ability training, project topic choice, project objectives decomposition and stepped degree to project implemented are designed to be more rigorous. At the same time, proposing through the optimization of curriculum, improving the teaching methods to provide theoretical support for the project, through the project supervision and evaluation mechanism to ensure the quality of the project completed [3-5] 


\section{PROJECT IMPLEMENTATION PLAN}

\section{A. Bring the "Project Practice Course" into the curriculum training system}

Through the revision of the training program, bring the "project practice course" into the biomedical engineering curriculum system, the entire course runs through the second to the fourth year [6]. Course start times, class hours are taken full into account of the convergence with the professional courses, the ease or complexity of each project and the implementation cycle are also considered. Specific arrangements are as follows: schedule the basic skills training in the second semester of the first year. The primary project have requirements for knowledge of theory, is offered in the sophomore year, when students start the specialized elementary course learning .In our school, professional core courses are mainly distributed in the third year, are divided into the mandatory classes and elective classes two parts. The professional elective courses are set up in different professional directions (medical instruments, image processing, biological materials, etc.), and adopt the credit accumulation and transfer system. So, the senior projects are arranged in this semester, students can accord to their own pre-project basis and follow-up project requirements to take reasonably, under the direction of the advisor. Which are conducive to mobilize the enthusiasm of students to learn professional core courses and improve the ability of comprehensive utilization knowledge. Through the pre-system training, students have a certain degree of engineering practice and innovation ability, we arrange innovative projects in the senior year, so that students can not only link the engineering projects to the graduation design, use the project innovation results as a graduate design, but also use to take State Undergraduate Innovative Training Program. The specific arrangement as Table 1 shows.

TABLE I. PROJECT LESSONS ARRANGEMENT

\begin{tabular}{|c|c|c|c|c|}
\hline \multirow{2}{*}{$\begin{array}{c}\text { Class } \\
\text { Hours }\end{array}$} & $\begin{array}{c}\text { The first } \\
\text { year } \\
\text { skills } \\
\text { training }\end{array}$ & $\begin{array}{c}\text { Project Distribution } \\
\text { Sophomore } \\
\text { Year primary } \\
\text { projects }\end{array}$ & $\begin{array}{c}\text { The third } \\
\text { year } \\
\text { senior } \\
\text { projects }\end{array}$ & $\begin{array}{c}\text { The senior } \\
\text { year } \\
\text { innovative } \\
\text { projects }\end{array}$ \\
\hline $\begin{array}{c}\text { The first } \\
\text { semester }\end{array}$ & 0 & 4 & 12 & 15 \\
\hline $\begin{array}{l}\text { the second } \\
\text { semester }\end{array}$ & 8 & 8 & 15 & 18 \\
\hline
\end{tabular}

\section{B. Preparation of "Project Practice Course" Teaching}

\section{Materials}

Project writing regard students as the subjects, project selecting adheres to the principle that "interest-driven, independent experiments, focusing on the process, pursuing innovation"[7-9]. Project content requirements reflect not only the comprehensive application of knowledge, but also the professional direction, subject development and forefront. Project level should consist with theory according to different teaching time, both interrelated and step by step. The primaryproject is the foundation of the senior project, and the senior project is the extension and expansion of the primary project.
According to the present biomedical engineering research field and our school biomedical engineering professional orientation, the project is set up to cover medical instrument, medical image processing, information engineering and biological material four modules. Students can choose one of the modules according to their own interests. In each module, according to sequence of the project, including professional basic skills, primary projects, senior projects, independent innovation projects 4 levels, each level parallel to open 5-8 independent projects. The specific arrangement as Table 2 shows.

TABLE II. PROJECT CONTENT

\begin{tabular}{|c|c|c|c|c|}
\hline \multirow{2}{*}{$\begin{array}{l}\text { Class } \\
\text { Hours }\end{array}$} & \multicolumn{4}{|c|}{ Project Level } \\
\hline & $\begin{array}{c}\text { Skills } \\
\text { training }\end{array}$ & $\begin{array}{l}\text { Primary } \\
\text { projects }\end{array}$ & $\begin{array}{c}\text { Senior } \\
\text { projects }\end{array}$ & $\begin{array}{c}\text { Innovative } \\
\text { projects }\end{array}$ \\
\hline $\begin{array}{l}\text { medical } \\
\text { instrument }\end{array}$ & $\begin{array}{l}\text { Skills1,2, } \\
3,4,5\end{array}$ & $\begin{array}{l}\text { Primary } \\
\text { projects } 1,2,3,4, \\
5\end{array}$ & $\begin{array}{l}\text { Senior } \\
\text { projects } 1,2,3 \text {, } \\
4,5\end{array}$ & $\begin{array}{l}\text { Innovative } \\
\text { projects } 1,2,3 \text {, } \\
4,5\end{array}$ \\
\hline $\begin{array}{l}\text { medical } \\
\text { image } \\
\text { processing }\end{array}$ & $\begin{array}{c}\text { Skills } 1,2, \\
3,4,5\end{array}$ & $\begin{array}{l}\text { Primary } \\
\text { projects } 1,2,3,4, \\
5\end{array}$ & $\begin{array}{l}\text { Senior } \\
\text { projects 1,2,3, } \\
4,5\end{array}$ & $\begin{array}{l}\text { Innovative } \\
\text { projects } 1,2,3 \text {, } \\
4,5\end{array}$ \\
\hline $\begin{array}{l}\text { information } \\
\text { engineering }\end{array}$ & $\begin{array}{l}\text { Skills } 1,2, \\
3,4,5\end{array}$ & $\begin{array}{l}\text { Primary } \\
\text { projects } 1,2,3,4, \\
5\end{array}$ & $\begin{array}{l}\text { Senior } \\
\text { projects } 1,2,3 \text {, } \\
4,5\end{array}$ & $\begin{array}{l}\text { Innovative } \\
\text { projects } 1,2,3 \text {, } \\
4,5\end{array}$ \\
\hline $\begin{array}{l}\text { biological } \\
\text { material }\end{array}$ & $\begin{array}{l}\text { Skills } 1,2, \\
3,4,5\end{array}$ & $\begin{array}{l}\text { Primary } \\
\text { projects } 1,2,3,4, \\
5\end{array}$ & $\begin{array}{l}\text { Senior } \\
\text { projects 1,2,3, } \\
4,5\end{array}$ & $\begin{array}{l}\text { Innovative } \\
\text { projects } 1,2,3, \\
4,5\end{array}$ \\
\hline
\end{tabular}

\section{Optimizing and Integrating The Course Design and Content}

The development of the project can not be separated from the theoretical knowledge. Bio -medical engineering is a cross-science concerning biology, medicine and engineering aspects, the characteristic of cross-science is comprehensive and complexity. Students need to master rich theoretical knowledge, but the biomedical engineering is completely different from clinical and biotechnology [10]. Knowledge teaching content should be aimed at biomedical engineering professional training direction and training objectives, and to optimize the selection, integration, both take into account of comprehensive, but also more focused on the knowledge application and innovation. For biomedical engineering, treat personalized training program is necessary. Medical and biology courses teaching are different from other majors in schedule, hours taking, the emphases and difficulties and other aspects. Selecting textbooks as "medical physics", "biomedical sensor", "medical treatment equipment", "medical test equipment".

\section{Improve teaching methods}

Although the project development is conducive to the cultivation of innovative ability, but the premise of innovation ability training is the formation of the innovative consciousness and the scientific thinking. With the studentsorientation in teaching, teachers can only play the role of guidance, offering study resources and setting up the cooperative study environment. Using elicitation method of teaching to train students to analyze and develop problemsolving skills, in the process of solving the problem to achieve 
creativity transformation and construct knowledge structure [11]. Schools and colleges can set up a Steering Committee and the Second Steering Committee respectively to strictly control the lesson design, teaching plan, collective lesson preparation, lectures, young teachers pre-test and other aspects; and organizing teaching matches to help young teachers improve their teaching skill. At the same time, schools and colleges should regularly arrange young teachers to go out to learn advanced teaching ideas and teaching methods, and apply them into the theoretical teaching.

\section{E. Project Supervision and management}

To ensure the quality of the project complete, carry out the group as a unit, and implement tutorial system [12]. From the project application to the final reply, from the primary project start to the advanced project progressive, the whole process carry out dynamic management, and mentor and academic management committee two levels of evaluation management mechanism [13-15]. Project application must be fully demonstrated, carry out only after the Tutor and Academic Management Committee have approved, and after basic skills training can apply for a primary project. A typical scenario is to introduce a hierarchical project management structure. Set phase objectives for each level of the project, break assignments down into smaller, only when students complete stage task, pass the examination can continue to conduct the flowing projects. At each evaluation, the instructor and the academic committee give the corresponding scores according to the completion of the student's stage goal, and give outstanding, good, pass mark, fail 4 class assess. If the project is operation feasible, innovative, recommend it to participate in "State Undergraduate Innovative Training Program" and a variety of design competitions.

\section{CONCLUSION}

Biomedical engineering, a new and developing course, training students use advanced engineering technology to solve the key issues in medicine and biology field, students' innovative ability will be directly related to China's medical and biology level in the world [16]. The results of the previous research show that the project practice itself is conducive to cultivating students' functional ability and practical ability. This research, through bringing engineering project into Biomedical engineering curriculum system will be more conducive to the gradual formation of innovative thinking. In addition, we through the project set, curriculum optimization, supervision and evaluation ways provide guarantees for the purpose. The research and its practice is expected to cultivate more outstanding innovative talents, make China a country of innovation in the future.

\section{ACKNOWLEDGMENT}

Supported by Shandong Provincial Higher Medical Education Research Center Education and Research Planning(YJKT201511)
Chinese Medical Association Medical Education Branch and China Higher Education Society of medical education professional committee 2016 medical education research project(2016B-RC074)

Weifang Medical College Education and Teaching Reform and Research Project (2015Y008).

Natural Science Foundation of Shandong Province(ZR2015HL097).

\section{REFERENCES}

[1] Zhao Xiaojiang, Zhao Xuanting, "Study and practice of innovation education for college students,". Journal of continuing education, china,2012,pp: 111 - 112. (In Chinese)

[2] Liu Mei, "Factors Affecting College Students' Innovative Ability and the Way to Cultivate Innovative Ability,”. Journal of Changsha University,china,2011,pp: 130 - 132. (In Chinese)

[3] Cai Liangwei, "Circuit and electronics experimental tutorial ,". Xi'an: Xi'an University of Electronic Science and Technology Press,china, 2012,pp: 121 - 157. (In Chinese)

[4] Ke Shanjie, Wei Zhichao, Chen Yuqian, Liu Shutong, Zhang Shuo, Zhang Rulin.," College students innovative training project to cultivate students' innovative ability research practice ," Education and Teaching Forum, china,2015, pp: 120-121. (In Chinese)

[5] Liu Changhong, Li Xiaohui, Li Gang, Yue Qingrong, Ren Yonggong. "Practice and Exploration of College Students' Innovative Entrepreneurship Training Program". Laboratory Research and Exploration, china,2014, pp: 163-166. (In Chinese)

[6] Tang Yu, Deng Xiang, Chen Guanghua. ""Optoelectronic information technology" research teaching exploration and practice ,". China Electric Power Education, china,2011, pp: 192-193. (In Chinese)

[7] Zhang Rui, Wang Dongmei."Study on the whole process management of college students' innovation training project , Journal of Experimental Technology and Management, china,2015, pp: 9-12. (In Chinese)

[8] Wu Junhua, Shi Junyou, Shen Dejun. “Innovative Training Program and Cultivation of College Students' Innovative Ability, ” Journal of Beihua University (Social Science Edition), china,2016, pp: 149-152. ( In Chinese)

[9] Ma Xiaoliang, Wang Fengchao, Wang Yue, Pi Jingwen,'Research on Undergraduate Talent Cultivation Based on Innovative Training Program for College Students - A Case Study of Beijing Forestry University School of Information," Computer Education,.china,2016, pp 124-129. (In Chinese)

[10] Tang Genli, Wang Yanbo,'Research on the Cultivation Path of College Students' Innovative Entrepreneurship ," Journal of Sichuan University of Science and Technology (Social Science Edition), 2011,pp: 76-79. ( In Chinese)

[11] HU Hejiu.'Undergraduate's creative talents cultivating ,"China's Higher Education Research, china,2003,pp : 75-76.

[12] WU Qian,Teng Gang,"Research of "Research Project" teachingmode and practice based on CEEUSRO,"Science and Technology in West of China, 2009, pp : 73-74. (In Chinese)

[13] WANG Xin-nian. Research of software engineering teaching systemin overall project mode [J] . Computer Education, 2012( 3) : 77 79. (In Chinese)

[14] SHAN Xiaolin,YU Qian,GUO Qiang," Engineering education reform and practice of research university in the new period,'Higher Education of Sciences,2010,pp : 25-26.

[15] CHEN Chunlin,FEI Ning. "Exploration of software talents training mode based on "Project-Driven"," Nanjing University ofAeronautics and Astronautics ( Social Sciences Edition ), 2009, pp : 81-84.

[16] FENG Lin,ZHENG Weiwei,"Research of innovative educational combine"Mission-Driven"with"Project-Driven"," HeilongjiangEducation,2010,pp: 57-59. 